\title{
Nigerian Professional Female Construction Workers in Vocational Occupations: Diversification or Deviation?
}

DOI 10.2478/otmcj-2018-0001

Received August 31, 2017; accepted December 29, 2017

\begin{abstract}
The construction industry did not just evolve on its own. It is a product of the conscious efforts of several individuals called construction workers. In Nigeria, it is a large employer of the population, skilled, unskilled, and professional. However, the Nigerian construction industry, similar to other industries, is currently in a phase of economic reform. This is largely attributed to the present economic situation. The current recession condition of the Nigerian economy has an adverse effect on the income of the citizenry. This implies that other sources of income alongside the basic firsthand means of income generation have to be sourced. This dilemma is more prominent among women. Considering the construction industry, professional female construction workers have been observed to join the league of those involved in ancillary income generation occupations. It is worth noting, however, that there are few professional female construction workers in the first place. This paper addresses whether this drift is a diversification or deviation of Nigerian professional female construction workers to vocational occupations, by a rigorous review of related literature. The result shows that this new trend among professional female construction workers is a welcome one if it is diversification because this will improve the productiveness of the individual involved and, in the long run, better the economy. On the other hand, this work finds that if these vocational occupations make professional female construction workers leave their construction field totally or almost totally, then there is a threat to female population in the construction industry. However, diversification is encouraged.
\end{abstract}

Keywords: construction, professional, female, Nigeria, vocation, economy

*Corresponding author: Tawakalitu Bisola Odubiyi, Federal University of Technology - Akure, Akure, Ondo State, Nigeria, E-mail: Kalitutawa@gmail.com

\section{Introduction}

There is a close relationship between construction in the UK and Nigeria: the UK being the colonial master of Nigeria, Nigeria's construction industry is run based on the UK model. An observation in a report by The Smith Institute (2016) reveals that in the UK, the construction industry is prone to run out of staff. This implies that female construction workers also might be affected. This is also noticed in Nigeria as women in the Nigerian construction industry are noticed to be involved in other vocational occupations such as dress making, beauty works, and other vocations beside their profession. Will this be termed deviation or diversification, because this is of paramount importance to the welfare of the Nigerian construction industry.

\subsection{Purpose}

Construction is a creative and developmental venture (Chukwuji Christian 2012); as such, it is opined that it provides the driving force necessary for sustaining economic buoyancy (Ugochukwu and Tobechuku 2014). Adeagbo (2014) added that the building and construction sector is seen to be very important in any nation's social and economic development. On a global scale, the construction sector is the world's largest industrial employer, with $7 \%$ of total world employment and $28 \%$ of industrial employment (Improving Working and Living Conditions in Construction 2014, p. 3). A report by the World Economic Forum (2016) agrees with this, stating that the construction (and engineering) industry strongly affects the economy, the environment, and society as a whole. It adds further that this industry touches the daily lives of everyone, as the quality of life is heavily influenced by the built environment surrounding people. However, there is a noticeable trend among professional female construction 
workers in Nigeria to engage in vocational occupations. To ascertain whether this is diversification or deviation is the purpose of this study.

\section{Methodology}

The approach used in this research is a critical review of related literature and the use of a questionnaire survey conducted among construction women professionals in Ondo State. The sample of this study consists of 42 questionnaires due to the low proportion of the targeted population. It addresses the subject matter as obtained from various materials such as journal articles, conference proceedings, reports, and others. It addresses the topic from a wider scope and boils it down to a narrower one.

\section{Literature Review}

\subsection{Construction Industry}

Construction activity cannot be overemphasized: it is an integral part of a country's infrastructure and industrial development (Barnabas et al. 2009). According to Babalola and Odediran (2013), construction plays an important role in the economic development of and employment in various nations. Nigeria is not exempt, as Ogunsemi and Jagboro (2006) elucidate that the Nigerian construction industry is important and significant to economic growth and employment generation. Olatunji and Bashorun (2006) noted that the industry has contributed substantially to economic growth (5\%-7\% improvement in the gross domestic product (GDP) growth, and $>42 \%$ of the fixed capital growth) over the past 4 decades, while on a global scale, the construction industry accounts for $6 \%$ of the GDP (Oluwakiyesi 2011). Therefore, the construction industry is an important sector. Diugwu et al. (2012) agree that the construction industry is regarded as the pillar of the domestic economy in many countries.

The construction industry did not just evolve on its own; it is a product of the conscious efforts of several individuals called construction workers. Construction workers are male and female, who are skilled, unskilled, or artisans. Aje and Awodele (2006) opined that the construction industry globally is an array of professionals, operatives, technicians, and laborers, as well as clients and contractors, working together toward the realization of a specific goal. As such, Cheung and Sueng (2002) purports that construction being a complex process, it requires the coordinated efforts of a temporarily assembled multiple-member organization of many discrete groups, each having to maximize its own benefits. This implies that construction is not only beneficial to the project at hand, it is also beneficial to the professionals on board and to the society as a whole; this makes it an important motivator for women in construction.

The professionals on board a construction project are commonly the land surveyor, architect, engineers, and quantity surveyor, among others. Odubiyi and Oke (2016) opine that the Nigerian construction industry is on the move as driven by the professionals on board. Olatunji et al. (2014) state that the Aachitect, engineer (structural and service), and quantity surveyors are some of the construction professionals. These categories of profession are made up of both genders.

\subsection{Women in Nigerian Construction Industry}

Fapounda (2012) states that the contributions of women to the national economy are increasingly being recognized. This is because women are increasingly involved in nation-building professions. However, in Nigeria today, as opined by Akomolafe and Mohammed (2014), in both industrial and academic facets of the construction industry, the rate of women's participation is particularly low. The reason for this is not far-fetched: the construction industry is a male-dominated industry. It is not a Nigerian problem only. A research report by The Smith Institute (2016) agrees that the construction industry in the UK is one of the largest employers of labor, yet $7 \%$ of the engineers are female, while the industrial classification of workers in Nigeria, as of 2008, according to the Japan International Cooperation Agency Report (2011) and Jimoh et al. (2016), states that only $0.2 \%$ of the population are female, as shown in Table 1.

They are employed in unskilled, administrative, and professional work, similar to that in the UK, majorly as administrators (Michielsens 2004). This corroborated the assertion of Clarke et al. (2005) that most women working in the construction industry within the European Union are administrators, technicians, and professionals rather than tradeswomen. From another perspective, Yusimit and Toni (2013) also pointed out that female construction workers constitute an example of occupational minority.

Yakubu (2003) explains the nature of the Nigerian construction industry as one that is built on a foundation 
Tab. 1: Classification of workers in Nigeria by the Federal Ministry of Women Affairs and Social Development according to industries, as of 2008.

\begin{tabular}{|c|c|c|c|c|}
\hline Industry & Female & Percentage & Male & Percentage \\
\hline Agriculture & $7,029,237$ & 36.5 & $12,207,075$ & 63.5 \\
\hline Fishing & 188,831 & 1 & 293,901 & 1.5 \\
\hline Mining & 40,301 & 0.2 & 152,860 & 0.8 \\
\hline Manufacturing industry & $1,197,538$ & 6.2 & $1,084,390$ & 5.6 \\
\hline Electricity, gas, and water & 68,582 & 0.4 & 233,072 & 1.2 \\
\hline Construction industry & 37,445 & 0.2 & 620,749 & 3.2 \\
\hline Retail trade & $5,796,543$ & 30.1 & $3,037,550$ & 15.8 \\
\hline Hotel/restaurant business & 163,561 & 0.9 & 53,557 & 0.3 \\
\hline Transportation and communication business & 96,300 & 0.5 & $1,308,250$ & 6.8 \\
\hline Finance business & 52,088 & 0.3 & 74,337 & 0.4 \\
\hline Real estate business & 187,984 & 1 & 226,263 & 1.2 \\
\hline Administration and defense & 477,061 & 2.5 & $1,352,562$ & 7 \\
\hline Education & 915,040 & 4.8 & 994,109 & 5.2 \\
\hline Health and social welfare & 292,143 & 1.5 & 183,185 & 1 \\
\hline Social services & 727,588 & 3.8 & $1,112,014$ & 5.8 \\
\hline House helper & 98,320 & 0.5 & 99,616 & 0.5 \\
\hline Others & 16,113 & 0.1 & 50,325 & 0.3 \\
\hline Total & $17,484,163$ & 43.1 & $23,053,815$ & 56.9 \\
\hline
\end{tabular}

Source: Adapted from Jimoh et al. (2016), cited in the report of the Japan International Cooperation Agency (2011).

of skilled craft workers, who are primarily supplied through various sources such as craft training institutions, vocational or technical colleges, on the job training, and apprenticeship. The report from Japan shows that $0.2 \%$ of construction workers in Nigeria, as of 2008, are female; as such, Kalpana and Kiran (2013) also report that of this percentage, the unskilled force contributes more. The implication of this is that there are fewer professionally certified female construction workers in Nigeria, just like in the UK, where only $6 \%$ of registered engineers and technicians (i.e. CEng, IEng, and EngTech) are women and $1.7 \%$ of Construction Skills candidates are women (WES Statistics 2016).

\subsection{Vocational Occupations}

The effects of vocational occupations in Nigeria are very pronounced. These occupations affect the personalities involved, the particular vocation itself, and the economy as a whole. Usually, some vocations grow into an industry. One such is fashion designing, which builds the fashion industry. Olubukola (2013) states that the fashion industry is a multibillion dollar industry globally. One of the effects of vocational occupations on the nation is seen in terms of tourism. The Nigerian Art and Culture Dictionary (2006) points out that tourism brings development and jobs to people living under low economic conditions. Vocational occupations birth thriving industries in Nigeria; examples include the fashion industry (Olubukola 2013), manufacturing industry, pharmaceuticals, and the entrepreneurship sector; this is likened to many strong sectors of the British economy, such as pharmaceuticals, digital technology, advanced manufacturing, and green technology, which require a large number of vocational skills (Institute for Public Policy Research 2014). A higher percentage of women are involved in these occupations (Fapounda 2012). In the past, vocational occupations were considered ideal for unlearned women, but recently, it is seen that educated women are involved in one vocational occupation or the other.

\subsection{Women in Vocational Occupations in Nigeria}

Women are the most vibrant and dynamic segment, as well as potentially the most valuable human resource, according to Diwakar and Ahamad (2015). This agrees with the claims of Bagshaw (2006) that women are better leaders, surpassing on skills such as creating and articulating vision, setting clear directions, taking charge, being an inspirational model, setting high standard of performance, and assuming responsibilities. A statement by Nigeria's Development Plan of 1962, as cited in Ofori (1980), posits that "Governments may govern, economists may plan, administrators may organize, but ultimately the execution of all plans, no matter how well designed and 
intentioned, depends upon the resources of the people themselves". The part that addresses people and their resources is a justification for women in vocational occupations in Nigeria, among other occupations.

Fapounda (2012) opined that women dominate the informal sector in Nigeria. The researcher further defined that the informal sector is the part of an economy that is not taxed, monitored by any form of government, or included in any gross national product (GNP). Ojo (1981) defined the informal sector as consisting of small-scale units engaged in the production and distribution of goods and services with the primary objective of generating employment and income, notwithstanding the constraints on capital, both physical and human, and the technical knowhow.

However, Soyibo (1997) observes that the activities of the informal sector are legal but unregulated. Usually, the informal sector is built on vocational occupations. Osondu (2016) explains vocation as the skill in doing a job successfully and directly developing expertise in techniques related to those particular trades that lead to a career. In relation to the informal sector, the African Development Fund Report (2005) opines that the informal sector represents an important part of the economy, and certainly of the labor market, and thus plays a major role in employment creation, production, and income generation in Nigeria.

\subsection{Present-Day Nigerian Economic System and Construction Industry}

Shittu and Shehu (2010) is of the opinion that the construction industry plays a key role in satisfying a wide range of physical, economic, and social needs and contributes significantly to the fulfillment of various major national goals. Isa et al. (2013) point out that there is a high correlation between economic growth and construction industry, as seen in Figure 1.

However, there has been a major hit in the Nigerian economy irrespective of the previous impacts on the construction industry. According to Eneji et al. (2016), the hit is the recession, caused by excessive imports, plunging oil revenue, and sharply low investment inflows. Nigeria, being an economy strongly relying on oil resources, feels the blow due to the fall in oil. As a result, according to PwC Economics and Policy (2015), imports quickly become more expensive, leading to strong inflationary pressures. Also, all non-oil growth sectors (construction inclusive) see their growth prospects fall.

Usually, when there is any effect in the economic situation, positive or negative, the citizenry feels it. According to documentation by BudgIT (2017), in 2016, Nigeria’s

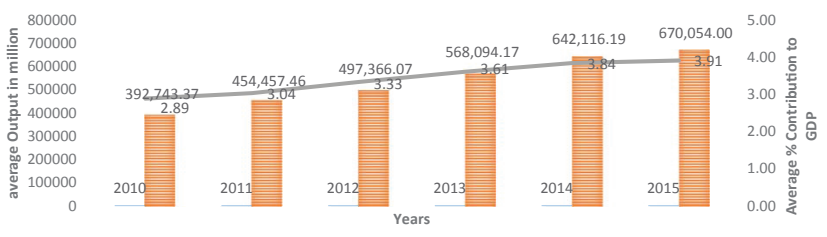

Fig. 1: Relationship between Construction industry and Economic Growth

Source: Adapted From Okoye et al (2016).

economy tipped into recession, largely due to oil price slumps and a trailing off of production. For the present economic situation, it implies that Naira has depreciated and the day-to-day source of income is not enough to handle the daily needs of the population. Isa et al. (2013) point out that there is a high correlation between economic growth and the construction industry.

\subsection{Professional Female Construction Workers and Vocational Occupations}

The African Development Fund (2005) reports that in Nigeria, the Federal Government of Nigeria increasingly views skills development as an important factor in the drive to enhance productivity, stimulate economic competitiveness, and raise people out of poverty. Diwakar and Ahamad (2015) agree that skills and knowledge are the driving forces of economic growth and social development of any country and the economy becomes more productive, innovative, and competitive through the existence of more skilled human potential. Women have been able to climb the ladder of their profession against several odds by becoming professionals. They have been able to create a niche of self-employment through several means; one such way is adding vocational occupation to their profession, even construction profession, despite its tedious nature. For emphasis, Shrestha (2016) opines that self-employment makes women (even professional female construction workers) more courageous, self-respectful, and enduring amid other opportunities. Self-employment is a counter-strategy against poverty, which is a subject of worldwide concern not leaving Nigeria, a developing country, behind.

Okurumeh (2016) is of the opinion that poverty is one of the national concerns as of today. It is a national concern because the citizens are affected. Women are usually more at the receiving end of any poverty effect. The reason for this can be traced to illiteracy or "aborted education", coupled with a lack of vocational skill (Fatimayin 2013). As such, women have risen to empower themselves against unemployment, underemployment, and poverty generally. Professional female construction workers are 
not left behind in empowering themselves with vocational occupations. Oladimeji (1995) in Ikechukwu and Najimu (2011) opined that acquisition of practical skills relating to occupation in various sectors of economic and social life will improve the standard of living of the people and assist in eradicating poverty in the society.

The central concern of human development is the quality of peoples' lives, what they are capable of doing (Donjor 2011). This implies that personal fulfillment is the ultimate goal of professional female construction workers, who are also involved in vocational occupations. Yusuff and Soyemi (2012) agree with the assertion that vocational skills are vital for individual prosperity. This noticeable trend can be viewed from the perspective of occupational diversification or occupation deviation: diversification in the sense that the main occupation is done along with the vocational occupation, and on the other hand, deviation if the main occupation is neglected for the vocational occupation.

\section{Results and Discussion}

\subsection{Motivational Factors for Vocational Occupation}

Table 2 depicts that the most important drive motivating professional female construction workers is occupational diversification, with a mean score of 3.45. This table also shows that passion for vocational occupation, self-empowerment to complement income, and self -satisfaction are the next motivating factors. These are the most important driving forces to vocational occupations. This is in tune with the assertions of Ganiyu et al. (2012) that one of the ways of achieving growth for a construction body is through diversification into other areas of businesses. Shrestha (2016) also agrees that self-empowerment and

Tab. 2: Motivating factors for professional female construction workers towards vocational occupations.

\begin{tabular}{lccc}
\hline Factor & $\begin{array}{r}\text { Mean } \\
\text { score }\end{array}$ & $\begin{array}{r}\text { Standard } \\
\text { deviation }\end{array}$ & $\begin{array}{c}\text { Factor } \\
\text { ranking }\end{array}$ \\
\hline Passion for vocational occupation & 3.41 & 1.106 & 2nd \\
Self-satisfaction & 3.31 & 0.975 & 5th \\
To complement income & 3.33 & 0.975 & 4th \\
Self-empowerment & 3.38 & 0.697 & 3rd \\
Underemployment & 3.05 & 0.697 & 6th \\
Poverty & 2.71 & 0.697 & 7th \\
Occupational deviation & 3.05 & 0.962 & 6th \\
Occupational diversification & 3.45 & 0.889 & 1st \\
\hline
\end{tabular}

self-satisfaction make women more courageous (even professional female construction workers in vocational occupations). These are the most important driving forces to vocational occupations. On a lower ranking, it is seen that underemployment and occupational deviation are not much motivating factors like the others.

\subsection{Classification of Trend}

Table 3 shows also that $64.3 \%$ of the respondents are of the opinion that the noticeable trend of professional female construction professionals is occupational diversification, while $35.7 \%$ believe that it is deviating from one's professional occupation. This is only limited to a few populations, according to the sample gathered.

\subsection{Effects of Trend on Construction Industry}

Table 4 shows that the noticeable trend has effects on several elements in the construction industry. This is supported by Bashiru et al., who propose that diversification has positive and negative effects on the individuals involved and the collaborating world concerned. Occupational diversification, with a mean score of 3.43 , is the first effect noticed on the industry. The next effect of this trend is reduction in the female team, with a mean score of 3.41; this aligns with the assertion of The Smith Institute (2016) that there is a projected loss of skilled labor over the next few years; this also indicates neglecting of one's

Tab. 3: Classification of trend.

\begin{tabular}{lccc}
\hline Classification & & Frequency & Percentage \\
\hline Occupational diversification & 1 & 27 & 64.3 \\
Occupational deviation & 2 & 15 & 35.7 \\
Total & & 42 & 100 \\
\hline
\end{tabular}

Tab. 4: Effects of trend on construction industry.

\begin{tabular}{lccc}
\hline Factors & Mean & $\begin{array}{c}\text { Standard } \\
\text { deviation }\end{array}$ & $\begin{array}{c}\text { Factor } \\
\text { ranking }\end{array}$ \\
\hline Reduction in female team & 3.41 & 0.939 & 2nd \\
Reduction in interest level of female & 3.26 & 0.701 & 4th \\
scholars & & & \\
Skilled staff reduction & 3.12 & 1.173 & 6 th \\
Fulfillment of major national goals & 3.38 & 1.125 & 3rd \\
Occupational deviation & 3.24 & 0.906 & 5th \\
occupational diversification & 3.43 & 0.887 & 1 st \\
\hline
\end{tabular}


profession, according to Ganiyu et al. (2012), since most concerned are women. It is also seen that this noticeable trends will lead to fulfillment of major national goals through female construction professionals. As maintained by Oladimeji (1995) in Ikechukwu and Najimu (2011), acquisition of practical skills relating to occupations in various sectors of economic and social life will improve the standard of living of the people and assist in eradicating poverty in the society. On the lower sides are effects such as occupational deviation and reduction in availability of skilled construction staff, as supported by the study of Ganiyu et al. (2012) that neglecting of profession has a negative effect on the construction industry, which can also be termed as occupational deviation.

\subsection{Effects of Occupational Diversification on the Economy}

The result of the survey in Table 5 depicts poverty reduction as the leading positive effect of occupational diversification, with a mean score of 3.67. Employment creation (3.48), creation of more industries (3.45), boosting of use of homemade products (3.36), solving financial issues (3.29), improvement in standard of living (3.24), increased personal earnings (3.24), skill diversification (3.10), and economic growth (3.10) are the closely following factors. On the lower side is increased production, with mean score of 3.05. These are all supported by the research of Ajani and Igbokwe (2013) that diversification leads to generation of additional income to empower themselves economically to meet their family obligations, thus reducing vulnerability and poverty among members of their households.

Tab. 5: Effects of occupational diversification on economy.

\begin{tabular}{lccc}
\hline Factors & Mean & $\begin{array}{c}\text { Standard } \\
\text { deviation }\end{array}$ & $\begin{array}{c}\text { Factor } \\
\text { ranking }\end{array}$ \\
\hline Solving financial issues & 3.29 & 0.835 & 6th \\
Employment creation & 3.48 & 0.917 & 2nd \\
Increased personal earnings & 3.24 & 1.144 & 7 th \\
Creation of more industries & 3.45 & 0.859 & 3rd \\
Skill diversification & 3.10 & 0.983 & 8th \\
Economic growth boost & 3.10 & 1.144 & 8th \\
Boosting the use of homemade & 3.36 & 1.008 & 5th \\
products & & & \\
Reduction in inflationary pressure & 2.88 & 1.173 & 10th \\
Increased production & 3.05 & 1.081 & 9th \\
Improvement in the standard of living & 3.24 & 1.206 & 7th \\
Poverty reduction & 3.67 & 1.097 & 1st \\
\hline
\end{tabular}

\section{Research Limitation}

This research is limited due to the small sample population, the results from which cannot be generalized for the whole Nigerian population, as a rigid test cannot be done for the statistical method applied.

\section{Conclusion and Recommendation}

\subsection{Conclusion}

This study has been able to identify that the new trend noticeable among professional female construction workers is largely a positive one. It is agreed that the question the research seeks to answer regarding diversification or deviation of professional female construction workers shows that it is mostly diversification as $64.3 \%$ of respondents agree it is. Diversification is a welcome change since it will enhance income generation for these professionals and, in the long run, boost the dying economic situation. This is supported by the theme that the central concern of human development is the quality of peoples' lives and what they are capable of doing (Donjor 2011). The study by Ajani and Igbokwe (2013) shows that diversification leads to generation of additional income to empower themselves economically to meet their family obligations, thus reducing vulnerability and poverty among members of their households. It also follows the remark by the Federal Government of Nigeria (1962) that "Governments may govern, economists may plan, administrators may organize, but ultimately the execution of all plans, no matter how well designed and intentioned, depends upon the resources of the people themselves".

\subsection{Recommendation for Further Studies}

It is recommended that further studies should be carried out to determine the possible threats that deviation of female construction professionals totally to vocational occupations can pose. It is also recommended that solutions to these possible threats should be drawn. In addition, diversification of female construction workers should be well addressed to achieve the full potential.

This should cover a wider range of population samples. Diversification should also not be limited to vocational occupations, but other occupations in which diversification is noticed, such as entrepreneurship, should be considered too. 


\section{References}

Adeagbo, A. (2014, December). Overview of building and construction industry in Nigeria. Journal of Research in National Development, 12(2), pp. 349-366. Available at from http://www.transcampus.org/journals; www.ajol.info/ journals/jorind.

African Development Fund. (2005). Skills Training and Vocational Education Project: Appraisal Report. Department of Social Development Centre and West Region, Nigeria.

Ajani, E., \& Igbokwe, E. M. (2013). Occupation deviation among rural women in Sub-Sharan African: A review. African Journal of Food, Agriculture, Nutrition and Development, 13(5), pp. 8224-8237.

Aje, I. O., \& Awodele, O. A. (2006). A study of the ethical values of quantity surveyors in Nigeria. In: Ogunsemi, P. D. (ed.), Ethical Issues and the Challenges in Construction Professionals' Service Delivery. Nigerian Institute of Quantity Surveyors, Ondo State Chapter, Akure, pp. 14-20.

Akomolafe, M. A., \& Mohammed, M. A. (2014). Gender barrier in construction industry. International Journal of Modern Management Sciences, 4(1), pp. 1-10.

Babalola, O., \& Odediran, S. J. (2013). Employment structure of informal construction workers/artisans in Nigeria. Global Journal of Management and Business Research Administration and Management, 13(1), pp. 1-17.

Bagshaw, N. (2006, November 26th). Voices from the Front Line. THISDAY, Nigeria.

Barnabas, A., Anbarasu, J. D., \& Clifford, P. S. (2009, November). A study on the empowerment of women construction workers as Masons in Tamil Nadu, India. Journal of International Women's Studies, 11(2).

Cheung, S., \& Sueng, H. G. (2002). A multi-attribute utility model for dispute resolution strategy selection. Construction Management and Economics, 20(7), pp. 557-568.

Chukwuji Christian, F. M. (2012, March). Factors Affecting Production and Quality in Construction Industry. Dissertation Report. Innovation Centre, University of Nigeria Nsukka, Nsukka, Nigeria.

Clarke, L., Pedersen, F., Michielsens, E., \& Susman, B. (2005). The European construction social partners: Gender equality in theory and practice. European Journal of Relations, 11(2), pp. 151-177.

Diugwu, I. A., Baba, D. L., \& Egila, E. A. (2012). Effective regulation and level of awareness: An exposé of the Nigeria's construction industry. Open Journal of Safety Science and Technology, 2, pp. 140-146.

Diwakar, N., \& Ahamad, T. (2015). Skills development of women through vocational training. International Message of Applied Research, 1, pp. 79-83.

Donjor, S. T. (2011, August). Skill Acquisition as a Tool for Poverty Reduction in Bayelsa, Nigeria. Masters of Science Degree Thesis. University of Nigeria Nsukka, Nsukka, Enugu, Nigeria.

Fapounda, A. (2012). Gender and development: challenges to women involvement in Nigeria's development. International Journal of Academic Research in Business and Social Sciences, 2(6), pp. 14-28.

Fatimayin, F. (2013). Effectiveness of Vocational Skills Acquisition Programme on Women: Empowerment: National Open University of Nigeria as Case Study. National Oen University of Nigeria, Lagos.
Ganiyu, O. B., Oyewobi, L. O., Nwokobia, L., \& Sulaiman, B. (2012). Diversification and Performance of Quantity Surveyors in Nigerian Construction Industry. In: RICS COBRA 2012, 11th-13th September 2012, Las Vegas, Nevada, USA by Arizona State University: Royal Institution of Chartered Surveyors.

Ikechukwu, O., \& Najimu, H. (2011). Public private partnership for skill acquisition and vocational technical education development in Nigeria. In: Proceedings of the 2011 International Conference on Teaching, Learning and Change. International Association for Teaching and Learning (IATEL), pp. 755-758.

Improving Working and Living Conditions in Construction. (2014). Addressing Needs Through International Labour Standards in Addressing Needs Through International Labour Standards in. Improving Working and Living Conditions in Construction. Available at http://www.bwint.org

Institute for Public Policy Research (IPPR). (2014). Winning the Global Race? Jobs, Skills and the Importance of Vocational Education. Institute for Public Policy Research (IPPR), London.

Isa, R. B., Jimoh, R. A., \& Achuenu, E. (2013). An overview of the contribution of construction sector to sustainable development in Nigeria. Net Journal of Business Management, 1(1), pp. 1-6.

Japan International Cooperation Agency. (2011). Final Report. Final Report on Country Gender Profile on Nigeria. Japan International cooperation Agency, Japan.

Jimoh, R. A., Oyewobi, L. O., Adamu, A. N., \& Bajere, P. A. (2016). Women professionals' participation in the nigerian construction industry: finding voice for voiceless. Organization, Technology and Management in Construction, 8, pp. 1429-1436.

Kalpana, D., \& Kiran, U. (2013, Sep-Oct). Status of female workers in construction industry in India: A review. IOSR Journal of Humanities and Social Science (IOSR-JHSS), 14(4), pp. 27-30.

Michielsens, E. S. (2004). The European construction social partner Gender equality in theory and practice. European Journal of Relations, 11(2), pp. 151-177.

Odubiyi, T. B., \& Oke, A. E. (2016). Strength, weakness, opportunity and threat of virtual team in Nigerian construction industry. Organization, Technology and Management in Construction, 8(1), pp. 1-7.

Ofori, G. (1980). The construction industries of developing countries: The applicability of existing theories and strategies for their improvement and lessons for the future, the case of Ghana. PhD Thesis, London: Bartlett School of Architecture and Planning, University College London.

Ogunsemi, D. R., \& Jagboro, G. O. (2006). Time-cost model for building projects in Nigeria. Construction Management Economics, 24, pp. 253-258.

Ojo, F. (1981). Nigeria's manpower planning experience. In: Ojo, F., Aderinto, A., \& Fasoyin (eds.), Manpower Development and Utilization in Nigeria: Problems and Policies. Lagos University Press, Lagos.

Okurumeh, E. A. (2016). Development of entrepreneurial skills through vocational education and information and communication technology (I.C.T) in Nigeria. International Journal of Science and Research (IJSR), 5(3), pp. 1746-1748. 
Olatunji, I. O., Oke, A. E., \& Owoeye, L. C. (2014). Factors affecting the performance of construction professionals in Nigeria. International Journal of Engineering and Advanced Technology, 3(6).

Olatunji, O. A., \& Bashorun, N. (2006). A system view of the labour profile structure of the construction industry in the developing countries: Nigeria, a case study. In: International Conference in the Built Environment in the Built Environment, ICIBE, Kuala Lumpur, pp. 881-892.

Olubukola, B. (2013). The Emerging Role of Fashion Tourism and the Need for a Development Strategy in Lagos, Nigeria. Degree Programme thesis, Kokkola-Pietarsaar Unit: Centria University of Applied Science.

Oluwakiyesi, T. (2011). National Accounts Vetica Research, Construction Industry Report: A Haven of Opportunities. Vetiva Capital Management Limited, Lagos.

Osondu, C. N. (2016). Entrepreneurship: Vocational skills to achieve sustainable economic growth. Journal of Sustainable Development Studies, 9(1), pp. 34-51.

PwC Economics \& Policy/Nigeria Economy Watch. (2015). What Next for Nigeria's Economy? Navigating the Rocky Road Ahead 2015 \& 2016. Available at http://www.pwc.com

Shittu, A. A., \& Shehu, M. A. (2010). Impact of building and construction investment on the Nigerian economy during the military era (1991 - 1998) and civilian era (1999 - 2006). Nigerian Journal on Construction Technology and Management, 11(1\&2), pp. 89-98.

Shrestha, G. K. (2016). Understanding the challenges of women in non-traditional occupations. Journal of Training and Development, 2, pp. 42-49.
The Smith Institute. (2016). Not Just for Boys-Women in Construction. The Smith Institute, London, UK.

Ugochukwu, C. S., \& Tobechukwu, O. (2014). Participation of indigenous contractors in Nigerian public sector construction projects and their challenges in managing working capital. International Journal of Civil Engineering, Construction and Estate Management, 1(1), pp. 1-27.

Women in Engineering Statistics (WES). (2016). Statistics on Women in Engineering. WES Statistics, UK.

World Economic Forum(Registered). (2016). Shaping the Future of Construction: A Breakthrough in Mindset and Technology. World Economic Forum (Registered), Geneva. Available at contact@weforum.org.

Yakubu, N. (8Th -11Th December, 2003). Technical and vocational education and training (TVET) in Nigeria: Issues and strategies. Final report of Sub regional seminar for West Africa titled, Implementing the UNESCO/ILO recommendations conference technical and vocational education and training. Technical and vocational education and training (TVET), Nigeria.

Yusimit, B., \& Toni, D. (2013). Gender dominated industries: Breaking through the glass ceiling. Journal of Academic and Business Ethics, 7, pp. 1-6.

Yusuff, M. A., \& Soyemi, J. (2012). Achieving sustainable economic development in Nigeria through technical and vocational education and training: The missing link. International Journal of Academic Research in Business and Social Sciences, 2(2), pp. 1-7. 